\title{
Factors affecting land transfer function and its impact on farmers income in Srigading Village, Sanden Sub-district, Bantul Regency
}

\author{
Wenang Anurogo *, Muhammad Zainuddin Lubis*, Hanah Khairunnisa** \\ *Department of Informatics Engineering, Geomatics Engineering Politeknik Negeri Batam, \\ Batam Kepulauan Riau \\ *Agency for the Assessment and Application of Technology (BPPT), Serpong Indonesia
}

\begin{tabular}{l}
\hline INFO ARTIKEL \\
\hline Riwayat Artikel: \\
Dikirim: $25-4-2018$ \\
Disetujui: $2-1-2019$ \\
Diterbitkan: $31-1-2019$
\end{tabular}

\section{Keywords:}

coastal area; land transfer function; remote sensing; farmer; shrimp ponds;

\begin{abstract}
ABSTRAK
Abstract: The coastal area is an area that has the potential to experience changes in land use. Coastal residents of Bantul and Kulon Progo districts utilize coastal land as dryland farming and fishery ponds. This study aims to determine the effect of land use change in the Srigading Village (especially for the conversion of shrimp ponds) to the farmers' income in the Village. This research uses the tools of remote sensing technology to identify land use change that happened in research area and combine with interview result data to know earnings difference from farmer. The result of the analysis shows that land use in coastal area of Srigading Village, Sanden Sub-District, Bantul Regency, before being used as shrimp pond is dominated by agricultural land and garden / moor. There are also settlements, and water area contained in the study area. Gardens/moor and agricultural land is a land that has the potential to switch function to shrimp farms as long as get enough brackish water supply. The distance is quite close to the beach and the river makes the land is very potential to switch functions into ponds. The results of the analysis also showed that farmers' income before and after shrimp farming in Srigading village experienced an average increase of almost $50 \%$.
\end{abstract}

\begin{abstract}
Abstrak: Kawasan pesisir merupakan wilayah yang berpotensi mengalami perubahan penggunaan lahan. Penduduk pesisir Kabupaten Bantul dan Kulon Progo memanfaatkan lahan pesisir sebagai pertanian lahan kering dan kolam perikanan. Penelitian ini bertujuan untuk mengetahui pengaruh perubahan penggunaan lahan di Desa Srigading (terutama untuk konversi tambak udang) terhadap pendapatan petani di desa. Penelitian ini menggunakan alat teknologi penginderaan jauh untuk mengidentifikasi perubahan penggunaan lahan yang terjadi di daerah penelitian dan digabungkan dengan data hasil wawancara untuk mengetahui perbedaan pendapatan dari petani. Hasil analisis menunjukkan bahwa penggunaan lahan di wilayah pesisir Desa Srigading, Kecamatan Sanden, Kabupaten Bantul, sebelum digunakan sebagai tambak udang didominasi oleh lahan pertanian dan kebun/tegalan. Ada juga pemukiman, dan area air yang terdapat di wilayah studi. Kebun/tegalan dan lahan pertanian adalah lahan yang berpotensi untuk beralih fungsi ke tambak udang selama mendapat pasokan air payau yang cukup.
\end{abstract}


Jaraknya yang cukup dekat dengan pantai dan sungai menjadikan tanah sangat potensial untuk beralih fungsi menjadi kolam. Hasil analisis juga menunjukkan bahwa pendapatan petani sebelum dan sesudah budidaya udang di desa Srigading mengalami peningkatan rata-rata hampir $50 \%$.

\author{
Address Correspondence: \\ Wenang Anurogo \\ Department of Informatics Engineering \\ Geomatics Engineering Politeknik Negeri Batam \\ Batam Kepulauan Riau, 29461 Indonesia \\ E-mail: wenang@polibatam.ac.id
}

\title{
INTRODUCTION
}

Coastal area is a specific area in which can be used as a tourism, settlement, and agriculture. The utilizations in the agriculture field as the paddy fields or fishery ponds. The example is along the southern coast of the Special Territory of Yogyakarta. In Gunung Kidul District, coastal residents utilize coastal areas as tourism areas, coastal residents of Bantul and Kulon Progo districts utilize coastal land as dry land farming and aquaculture.

Srigading is located in Sanden area, Bantul regency and is surrounded by coastal area. The village has a land that is less valuable economically. It has the coordinate of $-7.9 \mathrm{oS}$ and $110 \mathrm{oE}$. Mostly, the people in that area used the land as a rice fields. Farming of paddy fields has been considered less economical for the surrounding community. In 2014 there are initiatives from some residents to make land change. The form of land conversion done by farmers one of them to be a shrimp ponds.

According to Jayadinata (1992) land means area that already has the designation and generally has its owner (individual or institution). Land is a physical environment that includes soil, climate, relief, hydrology, and vegetation, where these factors affect its potential use (Hardjowigeno et al., 2001). Land use is in principle a reflection of the functions imposed on a plot of land. The pattern of land use reflects the human activities of the region that supports it. The community activity has positive correlation with the change of land use. Land that is often converted to function is agricultural land and forest used as settlement land. As a result of the land use change, there will be an environment imbalance, as well as an imbalance in social life. Shrimp farming business is one form of business activity that is supported by the three environmental factors. Physical factors include the physical environment, such as land and soil quality, climate, topography, quantity and quality of water, and so on (source). Geographic Information System (GIS) is a computer system that has 4 (four) capabilities in handling geographically referenced data that is input, output, data management (storage and data call), data analysis and manipulation. With these four capabilities the Geographic Information System can be used to identify areas prone to disaster (Anurogo et al, 2017). Based on Lubis (2017), using multi-temporal approached, it can be seen the change of land use form Parangtritis coastal area in 1992 - 2000. In addition, based on Kustriharyanto (2003) with case study of Maguwoharjo Village, Depok Subdistrict, Sleman Regency, the change of land use is concentrated in areas that have considerable accessibility to roads and village economic centers. Maulana (1999) used the method of map analysis and secondary data analysis in the form of descriptive and correlation analysis to observe the change of agricultural land use into non agriculture in Madiun Municipality 1986-1996 and it can be observed that the biggest change of land use is towards land use for settlement / housing. The study of land use change in Bantul regency 
has also been observed with the result of the change of agricultural land area into the largest non-agricultural land in Kasian area with the width of $112 \mathrm{Ha}(17.72 \%)$ and the lowest change in Kretek area of $1 \mathrm{Ha}(0.16 \%)$ (Muiz, 2009). Mapping of mangrove distribution was done by remote sensing technology using high-resolution image data.

Similar research will be conducted in the village of Srigading, Sanden, Bantul. This study aims to determine changes in coastal land use in the Village Srigading, Sanden, Bantul. The existence of this research is expected to know the difference of farmer's economic activity before and after land conversion and know the difference of farmer's income before and after land conversion.

\section{Location}

\section{METHODS}

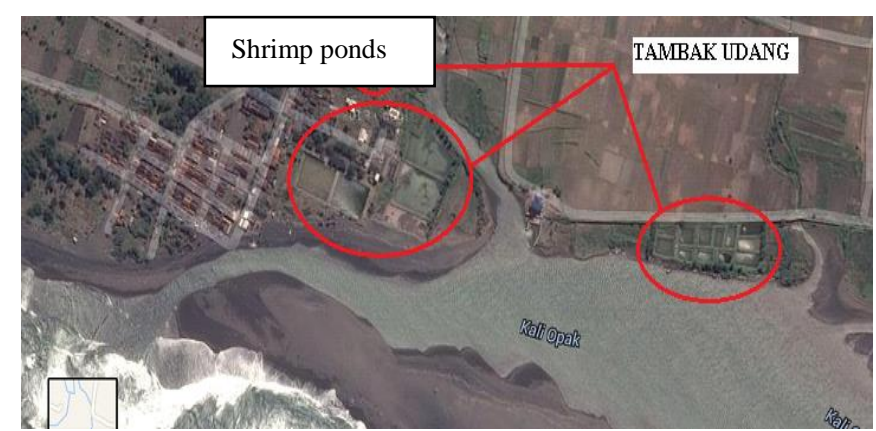

(Source: Google earth, 2017).

Figure 1. the location of shrimp ponds at the Srigading Village in the year of 2014

\section{Data}

The data used in this study are Quickbird Image data or images from the Google Earth study area of 2013 and 2014, RBI Map scale 1: 25,000 research areas, Srigading Village Monograph 2013, Sanden District in 2013 figures.

\section{The methods}

The data is processed by using mapping software to get the mapping of land use change. In addition, the method used is to perform a visual interpretation. Descriptive analysis and field observation are used by presenting tables, graphs, and diagrams to be able to see trends or comparisons of two variables. For the presentation of the results of differences in activities and income before and after the shrimp pond using a cross table or called crosstab.

\section{Data Downloading from Google Earth}

RESULTS AND DISCUSSION

The used data for knowing the distribution and extent of shrimp farm is taken from google earth image. This consideration is it can display the latest view of the research area so that expected information derived from the data can be accurate and update. The latest data from google earth is recording in June 2015. Google earth is used to visualization and communication (Lubis et al., 2017). The data may still be used but field checking is required to reduce the derived data to the original condition in the field. 
Jurnal Pendidikan Geografi:

Kajian, Teori, dan Praktik dalam Bidang Pendidikan dan Ilmu Geografi

Tahun 24, Nomor 1, Jan 2019, Hal 34-41

\section{Geometric Correction (Georeferencing)}

Geometric correction is the process by which the control points or binding points on the image are placed at the same points on the map or other corrected image. The existence of geometric distortion sources during image acquisition such as the effect of earth rotation, the curvature of the earth, the scanning speed of some abnormal sensors, and the panoramic effect cause the position of each object in the image is not the same as the actual geographical position of the earth's surface. To correct the distortion is done two stages (Gonzalez, 1977), which determines the function of transformation and resampling the image. Radiometric correction is required the ground control or Ground Control Point (GCP) data that can be extracted from topographic and petroleum maps or by utilizing Global Positioning System (GPS). The purpose of geometric correction is to place the image elements in planimetric positions ( $\mathrm{x}$ and $\mathrm{y}$ ) that are supposed to fit the actual state of the field (Anurogo et al., 2017).

The geometric correction has done in this google earth image is a non-systematic geometric correction done using a ground control point (GCP) (Shlien, 1979; Kardoulas et al., 1996; Rocchini and Rita., 2005; Anurogo et al., 2017). Non-systematic geometric correction uses first-order polynomial algorithms, since the physiographic conditions of the region are mostly terrain. Non-systematic geometric correction is performed by image to image registration with reference to georeferencing image map using base map of RBI scale of 1:25.000 which has been corrected, with Universal Transverse Mercator (UTM) projection system, WGS datum 1984. The study area was in $49 \mathrm{M}$ zone. The M zone was in the southern of equator.

The location is used as a place to take point Ground Control Point is a point that has the same appearance that can be identified from google earth. The taken appearance is a similar appearance and does not change fluctuate (not easy to change). Objects - these objects can be a fork road or a major intersection of roads or rivers. The number of GCP taken in one scene of this research image the more the better as long as according to its appearance and taken to spread on the whole image display.

\section{Land Cover Analysis}

The process of tapping the information from the first google earth data is to recognize and separate shrimp and non-shrimp ponds using visual interpretation. Due to the data from google earth it has a high resolution appearance so it is possible to recognize the visually visible appearance of the object in the image using the interpretation key (association texture hue, etc).

The visual interpretation resulted in the distribution of shrimp farms located in Srigading Village, Sanden Sub-District. The results of the interpretation are then processed so as to produce the value of the extent of each shrimp ponds in the study area.

\section{Field Survey}

A field survey was conducted to obtain the socio-economic information available in the research area according to the theme of the research. This field survey is conducted by interviews or by visiting relevant institutions or agencies that are appropriate to the data required for the research. This field survey was conducted to obtain data or information on the change or transfer of existing land functions in the study area, data on the work of the farmers before the shrimp ponds, data or information about the farmers' income before and after the shrimp farming in Srigading. 
Jurnal Pendidikan Geografi:

Kajian, Teori, dan Praktik dalam Bidang Pendidikan dan Ilmu Geografi

Tahun 24, Nomor 1, Jan 2019, Hal 34-41

These data were collected and combined with information obtained from previous analysis to obtain information on the effect of the shrimp pond on the income of farmers in the village of Srigading Village Sanden.

\section{Interpretation Accuracy Test}

Result of interpretation from data used got 2 (two) classes that is pond class and non pond class. The interpretation results are then tested with accuracy using table matrix error where the table is used to find out how big the error rate of interpretation classification results done. The accuracy can be seen in the table below error matrix.

Table 1. Interpretation Accuracy Test

\begin{tabular}{cccc}
\hline Interpre & Pond & Non pond & $\sum$ \\
\hline Pond & & & \\
\hline Non Pond & 25 & 2 & 3 \\
\hline$\sum$ & 27 & $\mathbf{1}$ & $\mathbf{3 0}$ \\
\hline
\end{tabular}

The calculation of Interpretation Accuracy:

Pond: $(25 / 27) * 100 \%=92.5 \%$

Non Pond: $2 / 3 * 100 \%=67 \%$

The calculation of the interpretation accuracy shows that there is little/almost no significant change for the pond interpretation class. The miss-interpretation for the pond class occurs more due to miss-interpretation or identification of the pond area whereas the field condition of the block is a pond belonging to the fisheries department. The interpretation error for the non-farming classes generated has changed considerably. This is because the data is used as the basic of interpretation is the recording data of July. It shows that the change of land for non-ponds into ponds in the study area is very large. This may be related to the needs of the people who will turn the profession into pond farmers large enough.

\section{Pond Condition}

The existing condition of the pond located in Srigading Village, Kretek Subdistrict, Bantul District, amounts to 30 blocks of ponds done by tambak farmers. Generally, a pond farmer work on a block of shrimp ponds. Each pond block has two irrigation sources to fill the water into the pond. The source of irrigation is freshwater wells and saltwater wells. Pond fillings use both sources of irrigation since shrimp-laden live is a brackish water habitat so a mixture of freshwater and brine should be appropriate. 
Jurnal Pendidikan Geografi:

Kajian, Teori, dan Praktik dalam Bidang Pendidikan dan Ilmu Geografi

Tahun 24, Nomor 1, Jan 2019, Hal 34-41

Table 2. The Wide of the Pond Area

\begin{tabular}{cccc}
\hline No & Wide $\left(\mathbf{m}^{\mathbf{2}}\right)$ & No & Wide $\left(\mathbf{m}^{\mathbf{2}}\right)$ \\
\hline 0 & 1398.02 & 16 & 1740.69 \\
\hline 1 & 1238.63 & 17 & 718.92 \\
\hline 2 & 2369.72 & 18 & 1335.19 \\
\hline 3 & 1511.55 & 19 & 940.12 \\
\hline 4 & 963.58 & 20 & 1276.03 \\
\hline 5 & 1893.35 & 21 & 324.02 \\
\hline 6 & 2217.06 & 22 & 288.09 \\
\hline 7 & 1504.38 & 23 & 160.26 \\
\hline 8 & 966.21 & 24 & 237.49 \\
\hline 9 & 1174.89 & 25 & 153.74 \\
\hline 10 & 489.22 & 26 & 192.96 \\
\hline 11 & 946.36 & 27 & 201.91 \\
\hline 12 & 587.49 & 28 & 1387.48 \\
\hline 13 & 833.50 & 29 & 1354.91 \\
\hline 14 & 1193.20 & 21 & 324.02 \\
\hline 15 & 1726.93 & &
\end{tabular}

\section{The Land Use Change}

The result of the analysis shows that land use in coastal area of Srigading Village, Sanden Sub-district, Bantul Regency before used as shrimp pond is dominated by agricultural land and garden / moor. There are also settlements, and water bodies in the study area. Land in the form of gardens / moor and agricultural land is a land that has the potential to switch function to shrimp farms as long as get enough brackish water supply. The distance is quite close to the beach and the river makes the land is very potential to change its function into ponds.

\section{The Income of Pond Farmers}

The pond farmers who located in Srigading Village, Sanden Sub-district, Bantul District previously had various livelihoods. Previously dominantly of these pond farmers as rice farmers. The others have livelihood as builders, traders, and fishermen. Their livelihood switching is due to various factors. The main factor is the greater and more certain income they get if being farmers ponds. The income received by the farmers is affected by the harvest from the ponds they work on, the better the shrimp farms they produce, the more salaries they receive. The average income that farmers receive is $1.4-1.5$ million per month. The additional income they get when the crops of shrimp farms they do good so that at the time after completion of harvesting they get an additional bonus from the owner of the pond. The bonus usually ranges from 1 thousand rupiah per kilo at the time of harvest. Income bonuses are also obtained when farmers are harvesting. 
Jurnal Pendidikan Geografi:

Kajian, Teori, dan Praktik dalam Bidang Pendidikan dan Ilmu Geografi

Tahun 24, Nomor 1, Jan 2019, Hal 34-41

Table 3. The Comparation of Pond Farmer Income

\begin{tabular}{|c|c|c|c|c|}
\hline No & Wide $\left(\mathbf{m}^{2}\right)$ & Previous Job & Income & Income for a month \\
\hline $\mathbf{0}$ & 1398.02 & Farmer & $\operatorname{Rp} 900.000$ & Rp 1.380.000 \\
\hline 1 & 1238.63 & Farmer & Rp 850.000 & Rp 1.500 .000 \\
\hline 2 & 2369.72 & Farmer & Rp 900.000 & Rp 1.400.000 \\
\hline 3 & 1511.55 & builder & Rp.750.000 & Rp 1.380 .000 \\
\hline 4 & 963.58 & salesman & Rp.750.000 & Rp 1.400 .000 \\
\hline 5 & 1893.35 & Fisherman & Rp 1.000 .000 & Rp 1.400 .000 \\
\hline 6 & 2217.06 & Farmer & Rp 900.000 & Rp 1.500 .000 \\
\hline 7 & 1504.38 & Fisherman & Rp.750.000 & Rp 1.400.000 \\
\hline 8 & 966.21 & Farmer & Rp.750.000 & Rp 1.500 .000 \\
\hline 9 & 1174.89 & Farmer & Rp.750.000 & Rp 1.400 .000 \\
\hline 10 & 489.22 & salesman & $\mathrm{Rp} 800.000$ & $\mathrm{Rp} 1.380 .000$ \\
\hline 11 & 946.36 & Farmer & $\operatorname{Rp} 900.000$ & Rp 1.400 .000 \\
\hline 12 & 587.49 & salesman & Rp.750.000 & Rp 1.380.000 \\
\hline 13 & 833.50 & salesman & $\operatorname{Rp} 850.000$ & Rp 1.400 .000 \\
\hline 14 & 1193.20 & builder & Rp 1.000.000 & Rp 1.500 .000 \\
\hline 15 & 1726.93 & fisherman & Rp 900.000 & Rp 1.400 .000 \\
\hline 16 & 1740.69 & builder & Rp 1.000.000 & Rp 1.380 .000 \\
\hline 17 & 718.92 & Farmer & Rp 850.000 & Rp 1.400 .000 \\
\hline 18 & 1335.19 & Farmer & Rp.750.000 & Rp 1.500.000 \\
\hline 19 & 940.12 & Farmer & $\operatorname{Rp} 900.000$ & Rp 1.380.000 \\
\hline 20 & 1276.03 & Farmer & Rp 900.000 & Rp 1.400.000 \\
\hline 21 & 324.02 & Salesman & Rp.750.000 & Rp 1.400 .000 \\
\hline 22 & 288.09 & Salesman & $\operatorname{Rp} 800.000$ & Rp 1.500 .000 \\
\hline 23 & 160.26 & Farmer & Rp.750.000 & Rp 1.400.000 \\
\hline 24 & 237.49 & Farmer & Rp.750.000 & Rp 1.500.000 \\
\hline 25 & 153.74 & Farmer & $\operatorname{Rp} 850.000$ & Rp 1.500.000 \\
\hline 26 & 192.96 & Farmer & Rp 900.000 & Rp 1.380 .000 \\
\hline 27 & 201.91 & Farmer & $\operatorname{Rp} 850.000$ & Rp 1.380 .000 \\
\hline 28 & 1387.48 & Farmer & $\mathrm{Rp} 900.000$ & Rp 1.380.000 \\
\hline 29 & 1354.91 & Carpenter & Rp 1.000.000 & Rp 1.600.000 \\
\hline
\end{tabular}

The result of the analysis is known that the income of the largest pond farmers is 1.6 million per month while the lowest income is 1.38 million per month. The additional income they receive varies depending on the owner of the pond.

\section{CONCLUSIONS}

The people activities of pond farmers in Srigading village prior to shrimp farming mostly work as farm laborers, some also work as fishermen, traders and construction workers. Farmers' income before and after shrimp farming in Srigading village experienced an average increase of almost $50 \%$.

\section{REFERENCES}

Anurogo, W., Lubis, M. Z., Pamungkas, D. S., \& Ibrahim, F. M. (2017). A Spatial approach to identify slum areas in East Wara Sub-Districts, South Sulawesi. In IOP Conference 
Jurnal Pendidikan Geografi:

Kajian, Teori, dan Praktik dalam Bidang Pendidikan dan Ilmu Geografi

Tahun 24, Nomor 1, Jan 2019, Hal 34-41

Series: Earth and Environmental Science (Vol. 98, No. 1, p. 012030). IOP Publishing.

Anurogo, W., Lubis, M. Z., Khoirunnisa, H., Hanafi, D. S. P. A., Rizki, F., Surya, G., and Dewanti, N. A. (2017). A Simple aerial photogrammetric mapping system overview and image acquisition using unmanned aerial vehicles (UAVs). GEOSPATIAL INFORMATION, 1(1).

Hardjowigeno and Widiatmaka. (2001). Land suitability and planning. Tataguna Tanah. Bogor: Jurusan Tanah Fakultas Pertanian IPB.

Jayadinata, J.T. (1992). Land use in urban and regional rural planning. Bandung: Penerbit ITB

Kardoulas, N. G., Bird, A. C., \& Lawan, A. I. (1996). Geometric correction of spot and landsat imagery: a comparison of map-and gps-derived control points. Photogrammetric Engineering and Remote Sensing, 62(10), 1173-1177.

Kustriharyanto, S. (2003). Faktor yang mempengaruhi perubahan penggunaan lahan di Desa Maguwoharjo Kecamatan Depok Kabupaten Sleman Yogyakarta. Skripsi, Yogyakarta: Fakultas Geografi UGM.

Lubis, M. Z., Anurogo, W., Gustin, O., Hanafi, A., Timbang, D., Rizki, F.. \& Taki, H. M. (2017). Interactive modelling of buildings in Google Earth and GIS: A 3D tool for urban planning (Tunjuk Island, Indonesia). Journal of Applied Geospatial Information, 1(2), 44-48.

Lubis, M. Z., Taki, H. M., Anurogo, W., Pamungkas, D. S., Wicaksono, P., \& Aprilliyanti, T. (2017). Mapping the distribution of potential land drought in Batam Island using the integration of remote sensing and geographic information systems (gis). In IOP Conference Series: Earth and Environmental Science (Vol. 98, No. 1, p. 012012). IOP Publishing.

Maulana, A. P., Ohmori, H., \& Sano, A. (1999). Friction compensation strategy via smooth adaptive dynamic surface control. In Control Applications, 1999. Proceedings of the 1999 IEEE International Conference on (Vol. 2, pp. 1090-1095). IEEE.

Muiz, A. (2009). Analysis of land use change in the Sukabumi District (Thesis). Sekolah Pascasarjana Institut Pertanian Bogor. Bogor.

Rocchini, D., \& Di Rita, A. (2005). Relief effects on aerial photos geometric correction. Applied Geography, 25(2), 159-168.

Shlien, S. (1979). Geometric correction, registration, and resampling of Landsat imagery. Canadian Journal of Remote Sensing, 5(1), 74-89. 